\title{
Process-oriented design principles for promoting self- regulated learning in primary teacher education
}

Citation for published version (APA):

Vrieling, E., Bastiaens, T., \& Stijnen, S. (2011). Process-oriented design principles for promoting self-regulated learning in primary teacher education. International Journal of Educational Research, 49(4-5), 141-150.

https://doi.org/10.1016/j.ijer.2011.01.001

\section{DOI:}

10.1016/j.jer.2011.01.001

Document status and date:

Published: 01/01/2011

Document Version:

Peer reviewed version

Please check the document version of this publication:

- A submitted manuscript is the version of the article upon submission and before peer-review. There can be important differences between the submitted version and the official published version of record. People interested in the research are advised to contact the author for the final version of the publication, or visit the DOI to the publisher's website.

- The final author version and the galley proof are versions of the publication after peer review.

- The final published version features the final layout of the paper including the volume, issue and page numbers.

Link to publication

\section{General rights}

Copyright and moral rights for the publications made accessible in the public portal are retained by the authors and/or other copyright owners and it is a condition of accessing publications that users recognise and abide by the legal requirements associated with these rights.

- Users may download and print one copy of any publication from the public portal for the purpose of private study or research.

- You may not further distribute the material or use it for any profit-making activity or commercial gain

- You may freely distribute the URL identifying the publication in the public portal.

If the publication is distributed under the terms of Article 25fa of the Dutch Copyright Act, indicated by the "Taverne" license above, please follow below link for the End User Agreement:

https://www.ou.nl/taverne-agreement

Take down policy

If you believe that this document breaches copyright please contact us at:

pure-support@ou.nl

providing details and we will investigate your claim.

Downloaded from https://research.ou.nl/ on date: 26 Apr. 2023 
Process-oriented design principles for promoting self-regulated learning in primary teacher education

E.M. Vrieling ${ }^{* a,}$, T. J. Bastiaens ${ }^{\text {bc }}$, S. Stijnen ${ }^{\text {b }}$

${ }^{a}$ IJsselgroep, Iselinge Hogeschool, Doetinchem, The Netherlands; ${ }^{b}$ RDMC, Open University, Heerlen, the Netherlands; ${ }^{c}$ Institut für Bildungswissenschaft und Medienforschung

Fernuniversität, Hagen, Germany

*Corresponding author. PO Box 277, 7000 AG, Doetinchem, the Netherlands. E-Mail address: emmy.vrieling@ijsselgroep.nl

Pre-print; published in International Journal of Educational Research, 49(4-5), 141-150. 
Many recent studies have stressed the importance of students' self-regulated learning (SRL) skills for successful learning. Consequently, primary teacher educators are stimulated by their policy makers to increase their students' SRL opportunities in the educational pre-service program. However, primary teacher educators often find it difficult to implement these innovations in their teaching. In the present study, a literature search concerning SRL was conducted. Based on this search, seven process-oriented design principles were formulated, resulting in a SRL model for primary teacher education. This SRL model provides more insight into relevant SRL aspects and can support SRL implementation in pre-service teacher education.

Keywords: higher education; pre-service teacher learning; process-oriented learning; scaffolding; self-regulated learning 


\section{Introduction}

This article describes the findings of a literature search concerning self-regulated learning (SRL) and aims at formulating design principles for primary teacher education. It critically discusses relevant and constraining factors that should be taken into account during the implementation of SRL in pre-service teacher education. The resulting recommendations can provide more insight for primary teacher educators (i.e. teachers of prospective primary teachers) into the SRL implementation process.

\subsection{Importance of SRL}

Several researchers (e.g.Hmelo-Silver, Duncan, \& Chinn, 2007; Simons, Van der Linden, \& Duffy, 2000; Zimmerman, 2002) stress the importance of students' SRL skills for successful learning. In general, SRL is defined as a goal-oriented process, proceeding from a forethought phase through self-monitoring and self-control to self-reflection (Pintrich, 2000, 2004). SRL can foster deep and meaningful learning as well as significant gains in student achievement.

As a result, in educational practice, new developments aimed at promoting students' SRL are increasingly being stimulated by policy makers. In the context of teacher education, student teachers (i.e. prospective primary teachers) are required to demonstrate a high degree of SRL by writing personal development plans, documenting their progress in a portfolio, monitoring their learning process and evaluating their results (Lunenberg \& Korthagen, 2003). In such learning environments, teacher educators must be able to structure the learning process in such a way that it allows and motivates student teachers to regulate their own learning. 
The fundamental idea behind this growing attention to SRL is epistemological in nature. In the field of cognitive psychology, social constructivist learning theories can be regarded as the leading paradigm in recent years (Loyens, 2007). These theories emphasize that learners should construct their own understanding. One of the shared assumptions of social constructivist learning theories is the importance of SRL as the key component for successful learning in school and beyond (Boekaerts, 1999; Zimmerman, 2001). SRL is regarded as an interaction of personal, behavioural and environmental factors (Pintrich, 2000; Zimmerman, 2000). SRL includes not only behavioural skills in self-managing environmental factors, but also the knowledge and the sense of personal agency to enact these skills in relevant contexts. Such monitoring leads to changes in learners' strategies, cognitions, affects and behaviour (Schunk \& Ertmer, 2000).

In line with this increasing epistemological attention for social constructivist views, the promotion of SRL is also influenced by societal developments (Bronneman-Helmers, 2007). Individuals increasingly strive for realizing their own choices. Due to this individualization process, there is more focus on individual students with their own talents (Bronneman-Helmers, 2007). Consequently, the educational setting must enable students to develop their individual talents and needs. In such classrooms, SRL opportunities can be very useful.

Furthermore, from an economical perspective, students have to be prepared for lifelong learning and working in a knowledge society (Kremer-Hayon \& Tillema, 1999; Zimmerman, 2002). Students are expected to master lifelong learning skills to be able to regulate their own learning once they are working in their fields of expertise (Van Eekelen, Boshuizen, \& Vermunt, 2005). 
Altogether, this focus on the construction of learners own understanding, combined with the rapid technological developments that can support this knowledge construction (BronnemanHelmers, 2007), have increased the interest in SRL in educational practice.

\subsection{Primary teacher education and $S R L$}

Teacher education is a field that traditionally focused on teaching subject knowledge and training teaching skills (Kremer, Hayon, \& Tillema, 1999). In recent years, however, researchers and practitioners in teacher education have been confronted with the lack of transfer from theory to practice. Student teachers are often not able to use the knowledge and skills provided in their own classrooms (Korthagen, Klaassen, \& Russell, 2000).

In answer to this problem, teacher educators are challenged to increase student teachers' SRL opportunities in the educational program (Kremer, Hayon, \& Tillema, 1999). Students who can better regulate their academic functioning are more successful in learning, problem solving, transfer and academic achievement in general (Nota, Soresi, \& Zimmerman, 2004; Sundre \& Kitsantas, 2004; Valle et al., 2003; VanderStoep, Pintrich, \& Fagerlin, 1996). That may also be the case with students in teacher education. In addition, the SRL concept can be very useful in the specific context of student teacher learning since student teachers can adopt this self regulation in their teaching (Kremer-Hayon \& Tillema, 1998).

As a consequence, student teachers have to learn as professionals and construct their own knowledge to develop an attitude of reflective inquiry and to experiment with ideas and teaching skills to enable lifelong learning (Kremer-Hayon \& Tillema, 1999).

\subsection{Problem definition}


Although teacher educators support the importance of the SRL concept (Kremer-Hayon \& Tillema, 1999), they often find it difficult to foster student teachers' SRL in the educational preservice program (Lunenberg \& Korthagen, 2005; Van Petegem, Donche, \& Vanhoof, 2005). Many practising teacher educators have not been prepared for this changing role during their education (Korthagen, Claassen, \& Russel, 2000) and are often worried about their decreasing role of knowledge provider (Kremer-Hayon \& Tillema, 1999). So, the professional development of teacher educators deserves more attention to increase student teachers SRL opportunities in the educational pre-service program (Könings, Brand-Gruwel, S., \& van Merriënboer, 2007).

To be able to provide more insight for primary teacher educators into relevant SRL aspects during teaching, the research question of this study was as follows: Which SRL principles for primary teacher education are distinguished in the literature? The present article represents a SRL search, aimed at describing a specific set of design principles for primary teacher education.

The article continues with a description of the literature search. Then, the findings from the literature search are outlined, resulting in process-oriented design principles for primary teacher education. These principles are summarized in a SRL model for primary teacher education. Finally, the findings are discussed and indications for future research are formulated.

\section{Review of the literature}

To be able to answer the research question, a literature review was carried out in four phases. In line with Cooper (1998), this method section reports the channels used, a rationale for the choices of sources, the years they cover and the key words that guide the search. 
The literature search started with searching in the databases of ERIC, PICARTA, GOOGLE SCHOLAR, DARE-net, ISED, Web of Science, Academic Search Complete, British Education Index, PsychINFO and the Social Sciences Citation index. These databases are well known and adequate for research in social studies. The following key words, all related to the research question, were used: self-regulated learning, self-regulation, self-directed learning, higher education, primary teacher education and pre-vocational teacher education. All key words were indexed in both singular and plural forms. Only contemporary studies conducted between 1990 and 2010 were selected. Furthermore, only journals that are registered by the Social Science Citation Index (SSCI) or by the Interuniversity Centre for Educational Research (ICO) were selected, because these are considered to be proper outlets for the articles.

During the second phase of the search process, the abstract, summary and references of all selected sources were studied. Five new key words turned out to be relevant: scaffolding, process-oriented learning, student-centred learning, academic performance, academic achievement and teacher training. All databases of phase one were searched again for these terms, repeating the first and second phase of the search process. In total, a number of 125 articles, 24 book chapters, 8 books, 8 dissertations and 4 reports were selected.

Next, all selected sources were read in depth. During this content analysis, the properties of the textual information were systematically identified by the frequencies of most used key words in the text. All selected sources had to be related to two large groups of key words namely 1) SRL/self-regulation/self-directed learning/student-centred learning/process-oriented learning, and 2) secondary education/ higher education/pre-vocational teacher education.

In the final phase, the selected sources were categorized by: 1) authors names and year of publication, 2) type of document, 3) location of the university of the first author, 4) type of 
research (conceptual versus empirical), 5) type of education, and 6) the main findings of the theoretical search (see Appendix A). Subsequently, the main findings were grouped into eight covering main themes: 1) importance of SRL, 2 knowledge building, 3) integration of content matter and metacognitive skills, 4) modeling of metacognitive skills, 5) scaffolding, 6) conditions, 7) collaboration, and 8) learning task. These main themes were also incorporated in Appendix A. The first theme represented a general theme that was used in section one of the present article The remaining seven themes provided the conceptual framework for section three of the present article, leading to the process-oriented design principles.

\section{Findings from the literature}

\subsection{Introduction}

In this section, theoretical findings concerning SRL are outlined, resulting in seven processoriented design principles for primary teacher education. Process-oriented teaching represents a way of teaching that facilitates students' use of SRL skills (Vermunt \& Verloop, 1999). The first set of six principles represents design principles that are necessary for a successful implementation of SRL in primary teacher education. These principles are described in the first part of this section. The seventh principle concerns an exploration of SRL with regard to the learning task (i,e, assignments student teachers have to accomplish) and is formulated in the second part of this section. At the end of the second part, all design principles are summarized and visualized in a SRL model for primary teacher education (Figure 1).

\subsection{Findings concerning a successful SRL implementation}

\subsubsection{Knowledge building}


Although the increase of students' SRL opportunities is recommended by several researchers (e.g. Simons, Van der Linden, \& Duffy, 2000; Zimmerman, 2002), disputes about the effectiveness of specific instructional practices derived from constructivism have been ongoing for at least the past half-century (Kirschner, Sweller, \& Clark, 2006). Eshel and Kohavi (2003) state that proper organization of the class is a prerequisite in the process of establishing a situation where SRL opportunities might lead to good academic performance. Teachers have to exert enough control on students' learning processes to enable them to achieve good academic results. A lack of metacognitive skills or knowledge might threaten the exploration of new insights during learning (Stijnen, 2003).

So, teachers cannot expect their students to regulate their learning all by themselves. Teachers are experts in the relevant subject-matter domain, and it is their task to make this domain more accessible to students (Bolhuis \& Voeten, 2001). This conclusion leads to the following principle when it comes to pre-service teacher learning: Focus on knowledge building in the domain (subject area).

\subsubsection{Metacognition and content matter}

When learning is conceived as self-regulated knowledge construction, the role of the teacher changes in the direction of supporting and guiding students' SRL (Vermunt \& Verloop, 1999). The aim of this process-oriented instruction is to integrate teaching of domain-specific knowledge on the one hand and learning and thinking strategies on the other (Vermunt \& Vermetten, 2004; Vermunt \& Verschaffel, 2000). Process-oriented instruction focuses on the processes of knowledge construction and utilization by the learners themselves. 
So, process-oriented teaching should focus on increasing both primary student teachers' content matter and metacognitive skills. Therefore, the following design principle is important: Integrate content matter and metacognitive skills during knowledge building.

\subsubsection{Modelling skills}

Teaching metacognitive skills demands overt and explicit demonstration of often hidden learning and thinking activities (Zimmerman, 2000), also in the context of teacher education (Kramarski \& Michalsky, 2009). However, teacher educators often find it difficult to serve as a role model (Lunenberg, Korthagen, \& Swennen, 2007). Schunk and Zimmerman (2007) describe a four phase social cognitive model of the development of SRL. Their research (Schunk, 1999; Zimmerman, 2000; Zimmerman \& Kitsantas, 2002) shows that the development of SRL can be positively mediated by using four regulatory skill levels during modelling, also among college students.

At the first level (observation), learners can induce the major features of the skill from watching a model learn or perform. At the second level (emulation), the learner imitates performances of a model's skill with social assistance. At the third level (self-control), the learner independently shows a model's skill under structured conditions. At the final level (selfregulation), the learner shows an adaptive use of skills across changing personal and environmental conditions. By using this modelling, teacher educators can make their teaching more explicit and improve the transfer between theory and educational practice (Lunenberg, Korthagen, \& Swennen, 2007). 
Altogether, it is recommended for primary teacher educators to model necessary metacognitive skills to their student teachers. During this process, the following phases are important: observation, emulation, self-control and self-regulation.

\subsubsection{Scaffolding}

To ensure successful knowledge building, Hmelo-Silver, Duncan, and Chinn (2007) stress the important role of teachers in providing considerable guidance to students. Kirschner, Sweller, and Clark (2006) emphasize the importance for students to possess sufficient high prior knowledge to be able to internally guide themselves. Only then the guidance of the teacher can decrease.

These findings indicate the importance of finding a balance between teacher-centred and student-centred learning in the curriculum, gradually moving from teacher to student regulation of the learning process. This step by step approach is often called scaffolding and was first introduced by Wood, Bruner, and Ross (1976). The metaphor of scaffolding is originally based on Vygotsky's zone of proximal development, referring to 'the notion that developing mental functions must be fostered and assessed through collaborative activities in which learners participate in constructive tasks of problem solving with the assistance of more knowledgeable others' (Windschill, 2002, 141).

To recapitulate, the following design principle can be put forward for primary teacher education: Move gradually from teacher control to student control over learning processes (scaffolding).

\subsubsection{Conditions}


Students in teacher education are increasingly being required to regulate their own learning without receiving explicit instructions on how to learn and without sufficient coaching and supervision (Taks, 2003). One well known problem in implementing curricula aimed at encouraging SRL is the risk that educational designers develop a design for a powerful learning environment, and teachers subsequently are not able to implement it in their teaching (Könings, Brand-Gruwel, \& van Merriënboer, 2007).

Vermunt and Verschaffel (2000) distinguish four factors that can hinder the implementation of process-oriented teaching in schools and universities, namely teacher characteristics, student characteristics, characteristics of learning materials and characteristics of the school context and culture.

Van Hout-Wolters, Simons, and Volet (2000) argue that an adequate preparation of teachers is necessary for a successful implementation of SRL in classrooms. The effective integration of SRL in the educational program requires teachers who understand and are convinced of the educational value of SRL (Windschill, 2002). Teacher educators may also lack the necessary knowledge and skills to implement SRL (Lunenberg \& Korthagen, 2005; Putnam \& Borko, 2000).

Student teachers too may have ideas about and preferences for learning and teaching that are contrary to appreciating process-oriented learning (Van Petegem, Donche, \& Vanhoof, 2005). Furthermore, learners are not always motivated to invest much time and energy in developing adequate learning skills (Van Hout-Wolters, Simons, \& Volet, 2000).

Many learning materials are not suitable for SRL based learning environments. For example, smooth implementation can be threatened by classrooms that do not allow for 
individual or group work (Könings, Brand-Gruwel, \& van Merriënboer, 2007; Vermunt \& Verschaffel, 2000).

The school context and culture may also be obstacles to implementing an innovative design like process-oriented learning (Könings, Brand-Gruwel, \& van Merriënboer, 2007; Van Hout-Wolters, Simons, \& Volet, 2000; Vermunt \& Verschaffel, 2000). Fluent implementation can be impeded by a lack of time, large group sizes, applying a school evaluation system that neglects process-oriented variables, etc.

In conclusion, the following design principle can be noted for primary teacher education: Be aware of the conditional factors that influence the implementation of SRL in the curriculum. Pay attention to an adequate preparation of teacher educators, the comprehension of the significance of SRL by student teachers, the use of adequate learning materials and an appropriate school context and culture.

\subsubsection{Collaboration}

Student collaboration plays a facilitative role in developing SRL (Wigfield, Hoa, \& Klauda, 2007). When students have collaborative projects to complete, they make special effort to ensure that they make a helpful contribution to the group. Also, encouraging students to consult with peers can lead to taking good advantage of their classmates as knowledge resources. For that reason, learning processes and results should be regarded as social phenomena (Bolhuis \& Voeten, 2001). To facilitate student teachers' reasoning and sustain their interest and engagement, teacher educators have to guide peer interactions (Norton \& Hathaway, 2010) by insuring positive interdependence in the group, giving clear instructions on how to co-operate and providing adequate feedback on the co-operating process (Bolhuis \& Voeten, 2001). 
In short, the sixth design principle is as follows: Engage student teachers in collaborative learning environments. Pay attention to positive interdependence, clear instructions and feedback on the working process.

\subsection{Findings concerning the learning task}

\subsubsection{Goal setting}

Academic goals are regarded as important variables in current motivational research, because they serve as self-defining reference points that determine the further processes of SRL, such as planning, executing and monitoring (Schunk \& Ertmer, 2000; Zimmerman, 1999). Goals are cognitive representations of the various aims that students can adopt in different achievement situations (Valle et al., 2003).

Summarizing the findings of several researchers (e.g. Dembo and Eaton, 2000; Eccles \& Wigfield, 2002; Schunk \& Ertmer, 2000; Zimmerman 2007), the following goal categories need to be taken into account to create more successful SRL: 1) goals concerning learning processes, 2) personal learning goals, 3) short- and long-term goals, 4) conscious goals, 5) specific goals, 6) proximal goals, 7) challenging goals.

\subsubsection{Prior knowledge activation}

Prior knowledge activation enables individuals to understand the task and its goals, to recognize the required knowledge for performing it and to distinguish the several characteristics and their prediction of performance (Eilam \& Aharon, 2003). In this way, prior knowledge facilitates individuals to monitor, behave accordingly, judge results in relation to goals and construct more appropriate conditional knowledge for better performance in the future (Butler \& Winne, 1995). 


\subsubsection{Metacognitive knowledge activation}

The activation of metacognitive knowledge in the SRL forethought phase (Pintrich, 2000, 2004) includes the activation of knowledge about cognitive tasks and cognitive strategies. Butler and Cartier (2004) distinguish three interrelated characteristics within tasks: task purpose (goals), task structures and task components. To be successful, students must have productive metacognitive knowledge about tasks concerning each of these components.

\subsubsection{Metacognitive awareness and monitoring of cognition}

As part of the knowledge that they construct, students develop metacognitive knowledge, which influences their approaches to academic tasks (Butler \& Cartier, 2004). Metacognitive regulation activities are those thinking activities that students use to decide on learning contexts, to exert control over their processing and affective activities and to steer the course and outcomes of their learning (Vermunt \& Verloop, 1999). Metacognitive monitoring skills are a core component within information processing models of self-regulation (Butler, 2002; Nietfeld, Cao, \& Osborne, 2006).

Effective self-regulated learners generate internal feedback as they monitor their engagement with learning activities and tasks and assess progress towards goals (Butler \& Winne, 1995). During this self-evaluation, students compare self-observed performance to an absolute standard or prior performance (Zimmerman, 2002).

Effective self-regulated learners also actively interpret external feedback, for example, from teachers and other students, in relation to their internal goals. External feedback has shown to be a critical educational intervention for developing students' SRL (Nicol \& Macfarlane-Dick, 
2006). According to Hattie and Timperly (2007), effective external feedback needs to be clear, purposeful, meaningful, and compatible with students' prior knowledge to provide logical connections. Furthermore, it needs to encourage students' active information processing, have low task complexity, relate to specific and clear goals, and provide little threat to students' feelings of self-efficacy.

\subsubsection{Judgements}

In the SRL self-reflection phase, Pintrich $(2000,2004)$ distinguishes two key processes. The first process involves learners' judgements and evaluations of their performance of the task. One of the principles within this process is to help students clarify what good performance is, using task requirements (Butler, 2002; Butler \& Cartier, 2004; Nicol \& Macfarlane-Dick, 2006). Another principle is to facilitate the development of self-assessment. Students need to learn to make judgements about the way their work relates to the criteria (Hattie \& Timperley, 2007; Nicol \& Macfarlane-Dick, 2006).

\subsubsection{Attribution}

The second process of the SRL self-reflection phase concerns students' attributions for performance. Attributions are beliefs concerning the causes of outcomes (Butler, 2002; Schunk, 2007). Such beliefs influence students' motivation for SRL. If students use adaptive attributions, they believe that poor performance is caused by low effort or poor strategy use and not by lack of general ability. These beliefs can result in deeper cognitive processing and better learning and achievement (Pintrich, 2000). Educators can facilitate effective self-regulation by providing 
attributional feedback to students which stresses factors students can control, such as effort and strategy use (Schunk, 2007).

\subsubsection{Task value activation}

Task value beliefs include perceptions of the relevance, utility and importance of the task (Pintrich, 2000). Eccles and Wigfield (2002) outline four components of task value: attainment value, intrinsic value, utility value and cost. They define attainment value as the personal importance of doing well on the task. Intrinsic value is the enjoyment the individual gets from performing the activity or the subjective interest the individual has in the subject. Utility value is determined by how well a task relates to current and future goals, such as career goals. Finally, cost is conceptualized in terms of the negative aspects of engaging in the task, such as performance anxiety and fear of both failure and success, as well as the amount of effort needed to succeed, and the lost opportunities that result from making one choice rather than another.

\subsubsection{Time management}

Time management involves making schedules for studying and allocating time for different activities (Pintrich, 2000) and is an important component of SRL (Dembo \& Eaton, 2000). The key factor of time management is prioritizing activities each day. Students make decisions and form intentions about how they will allocate their effort and the intensity of their work.

\subsection{Construction of the SRL model}

In this section, the findings from the literature were discussed, aimed at formulating relevant SRL recommendations for primary teacher education. Seven process-oriented design principles 
were distinguished. All design principles are theoretically underpinned in this article and outlined in the SRL model for primary teacher education (Figure 1).

Figure 1. SRL model for primary teacher education

\section{LEARNING PROCESS}

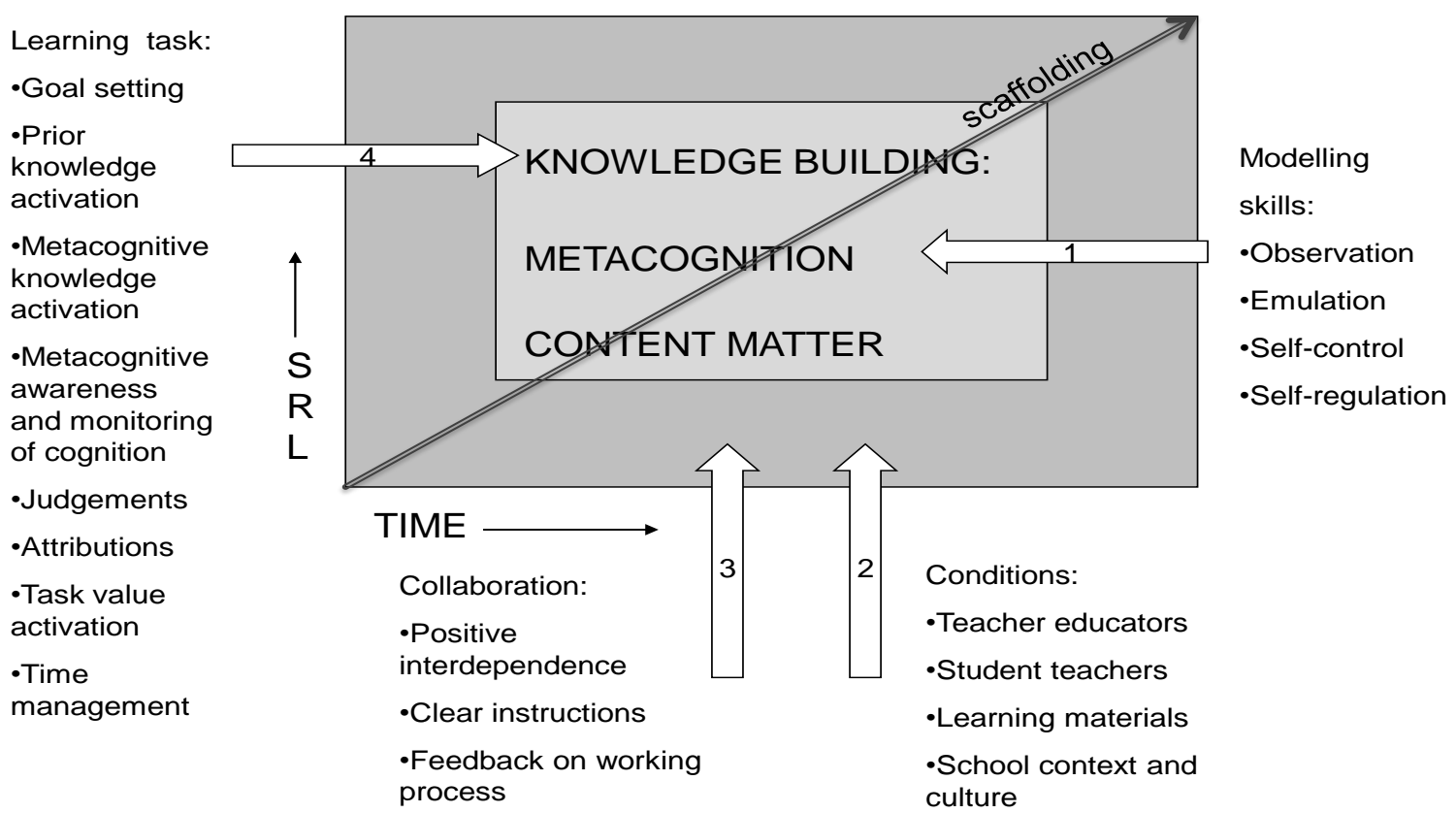

In this SRL model, the learning process of student teachers is visualized. As can be seen in the centre of the SRL model (knowledge building), the literature search revealed the importance for teacher educators to create a sufficient knowledge base for student teachers in the domain (subject area). Teacher educators have to play a key role in facilitating this knowledge building by integrating the necessary metacognitive skills and content matter during teaching. The importance of modelling these metacognitive skills is drawn by arrow 1 (pointing at the metacognitive concept), representing four regulatory skill levels, namely observation, emulation, self-control and self-regulation. Furthermore, to ensure successful knowledge building, a gradual 
development from teacher control to student control over learning processes (scaffolding) was stressed. This gradual increase in SRL is also displayed in Figure 1 by the diagonal arrow. Besides the importance of successful knowledge building, awareness of the conditional factors that can hinder or foster SRL development is necessary. Arrow 2 shows the influence of these conditions on the learning process. It was emphasized to prepare teacher educators adequately for their job, to ensure the comprehension of significance by student teachers, to use suitable learning materials for SRL and to create an appropriate school context and culture.

Also, the engagement of student teachers in collaborative learning environments was discussed. Arrow 3 indicates the influence of collaboration on the learning process. Three pieces of advice for teacher educators were explained: ensure positive interdependence in the group, provide clear instructions to student teachers and provide adequate feedback on their working process.

In the end, the relevant SRL aspects of the learning task were explored. This is visualised by arrow 4 (pointing at the knowledge building concept). These SRL aspects concern goal setting, prior knowledge activation, metacognitive knowledge activation, metacognitive awareness and monitoring of cognition, judgements, attributions, task value activation and time management.

\section{Discussion}

Primary teacher educators are confronted with the necessity of facilitating through instruction and demonstration the adaption by student teachers of SRL principles. This literature review provides a range of sources through which to explore SRL and opens up some key debates, including how best to facilitate SRL and likely constraining factors. 
The large majority of the elements incorporated in the present study address issues or areas that have received significant research attention over a large time span. By presenting them in a clarifying SRL model including seven process-oriented design principles, more insight into relevant SRL aspects is provided. The design principles can be considered in designing programs for primary teacher education. In this way, the SRL model supports SRL implementation in the educational pre-service program

Some critical remarks about this study can be made. The design principles are based solely on a literature review. Despite the systematic inquiry method of the literature search, the validity of conclusions cannot be taken for granted (Cooper, 1998). Combining separate SRL studies into a new design for primary teacher education involves inferences as central to the validity of knowledge.

An innovative design like SRL needs to be explicit about the teaching behaviors expected from the teachers (Könings, Brand-Gruwel, S., \& van Merriënboer, 2007). Therefore, in a follow up study, the SRL model is used for the development of a diagnostic instrument for primary teacher education. Such an instrument can support primary teacher educators during diagnosing and gradually increasing student teachers' SRL opportunities in the educational preservice program. In this way, a better balance between student-centered and teacher-centered approaches in primary teacher education can be achieved.

\section{Acknowledgements:}

This research was supported by the Zestor foundation under project number PRO634-B-E. 


\section{References}

Boekaerts, M. (1999). Self-regulated learning: Where we are today. International journal of Educational Research, 31, 445-457.

Bolhuis, S. \& Voeten, M.J.M. (2001). Toward self-directed learning in secondary schools: What do teachers do? Teaching and Teacher Education, 17, 837-855.

Bronneman-Helmers, H.M. (2007). Vijftien jaar onderwijsvernieuwingen in Nederland: Een beleidsanalytische studie ten behoeve van het parlementair onderwijs onderwijsvernieuwingen [Fifteen years of educational reform in the Netherlands: A policy analytic study on behalf of the parliament of educational innovation] 's Gravenhage: Sdu Uitgevers.

Butler, D.L. (2002). Individualizing instruction in self-regulated learning. Theory into Practice, $41,81-92$.

Butler, D.L., \& Cartier, S.C. (2004). Promoting effective task interpretation as an important work habit: A key to successful teaching and learning. Teachers College Record, 106, 17291758.

Butler, D.L., \& Winne, P.H. (1995). Feedback and self-regulated learning: A theoretical synthesis. Review of Educational Research, 65, 245-281.

Cooper, H. (1998). Synthesizing research: A guide for literature reviews, 3rd ed.. Thousand Oaks, CA: Sage Publications.

Dembo, M.H., \& Eaton, M.J. (2000). Self-regulation of academic learning in middle-level schools. The Elementary School Journal, 100, 473-490.

Eccles, J.S., \& Wigfield, A. (2002). Motivational beliefs, values, and goals. Annual Review of Psychology, 53, 109-132. 
Eilam, B., \& Aharon, I. (2003). Students' planning in the process of self-regulated learning. Contemporary Educational Psychology, 28, 304-334.

Eshel, Y., \& Kohavi, R. (2003). Perceived classroom control, self-regulated learning strategies, and academic achievement. Educational Psychology, 23, 249-260.

Hattie, J., \& Timperly, H. (2007). The power of feedback. Review of Educational Research, 77, $81-112$.

Hmelo-Silver, C.E., Duncan, R.G., \& Chinn, C.A. (2007). Scaffolding and achievement in problem-based and inquiry learning: A response to kirschner, Sweller, and Clark (2006). Educational psychologist, 42, 99-107.

Kirschner, P.A., Sweller, J., \& Clark, R.E. (2006). Why minimal guidance during instruction does not work: An analysis of the failure of constructivist, discovery, problem-based, experiential, and inquiry-based teaching. Educational Psychologist, 41, 75-86.

Könings, K.D., Brand-Gruwel, S., \& van Merriënboer, J.G. (2007). Teachers' perspectives on innovations: Implications for educational design. Teaching and Teacher Education, 23, 985-997.

Korthagen, F., Klaassen, C., \& Russell, T. (2000) New learning in teacher education. In P.R-J. Simons, J. van der Linden, \& T, Duffy [eds.], New learning (pp. 243-259). Dordrecht: Kluwer Academic Publishers.

Kramarski, B., \& Michalsky, T. (2009). Preparing preservice teachers for self-regulated learning in the context of technological pedagogical content knowledge. Learning and Instruction, $20,434-447$.

Kremer-Hayon, L., \& Tillema, H.H. (1999). Self-regulated learning in the context of teacher education. Teaching and Teacher Education, 15, 507-522. 
Loyens, S. (2007). Students' conceptions of constructivist learning (Doctoral dissertation, Erasmus University, the Netherlands). Retrieved from http://publishing.eur.nl/ir/repub/asset/9264/Sofie\%20Loyens\%20Proefschrift.pdf

Lunenberg, M., \& Korthagen, F.A.J. (2003). Teacher educators and student-directed learning. Teaching and Teacher education, 19, 29-44.

Lunenberg, M., \& Korthagen, F.A.J. (2005). Breaking the didactic circle: a study on some aspects of the promotion of student-directed learning bij teachers and teacher educators. European Journal of teacher Education, 28, 1-22.

Lunenberg, M., Korthagen, F., \& Swennen, A. (2007). The teacher educator as a role model. Teaching and Teacher education, 23, 586-601.

Nicol, D.J., \& Macfarlane-Dick, D. (2006). Formative assessment and self-regulated learning: A model and seven principles of good feedback practice. Studies in Higher Education, 31, 199-218.

Nietfeld, J.L., Cao, L., \& Osborne, J.W. (2006). The effect of distributed monitoring exercises and feedback on performance, monitoring accuracy, and self-efficacy. Metacognition and Learning, 1, 159-179.

Nota, L., Soresi, S., \& Zimmerman, B.J. (2004). Self-regulation and academic achievement and resilience: A longitudinal study. International Journal of Educational Research, 41, 198215.

Norton, P. \& Hathaway, D. (2010). Online conversations with peers and with expert mentor: Is there a difference? In C. Maddux, D. Gibson, \& B. Dodge (eds.), Research highlights in technology and teacher education (pp. 19-26). SITE. Retrieved from http://www.editlib.org/p/35314. 
Pintrich. (2000). The role of goal orientation in self-regulated learning. In M. Boekaerts, P.R. Pintrich, \& M. Zeidner (eds.), Handbook of self-regulation (pp. 451-502). San Diego, CA: Academic Press.

Pintrich, P.R. (2004). A conceptual framework for assessing motivation and self-regulated learning in college students. Educational Psychology Review, 16, 385-407.

Putnam, R.T., \& Borko, H. (2000). What do new views of knowledge and thinking have to say about research on teacher learning? Educational Researcher, 29, 4-15.

Schunk, D.H. (1999). Social-self interaction and achievement behaviour. Educational Psychologist, 34, 219-227.

Schunk, D.H. (2007). Attributions as motivators of self-regulated learning. In D. H. Schunk \& B.J. Zimmerman [eds.], Motivation and self-regulated learning (pp. 245-266). New York: Lawrence Erlbaum Associates.

Schunk, D.H., \& Ertmer, P.A. (2000). Self-regulation and academic learning. In M. Boekaerts, P.R. Pintrich, \& M. Zeidner (eds.), Handbook of self-regulation (pp. 631-649). San Diego, CA: Academic Press.

Schunk, D.H., \& Zimmerman, B.. (2007). Influencing children's self-efficacy and self-regulation of reading and writing through modelling. Reading and Writing Quarterly, 23, 7-25.

Simons, P. R-J., Linden, J. van der, \& Duffy, T. (2000). New learning: three ways to learn in a new balance. In P.R-J. Simons, J. van der Linden, \& T, Duffy [eds.], New learning (pp. 1-20). Dordrecht: Kluwer Academic Publishers.

Stijnen, P.J.J. (2003). Leraar worden: 'Under construction'? Over leraartekorten en afstandsonderwijs voor de opleiding tot leraar [Becoming a teacher: 'Under 
construction'? About teacher shortages and distance education for teachers]. Maastricht: Shaker Publishing BV.

Sundre, D.L., \& Kitsantas, A. (2004). An exploration of the psychology of the examinee: Can examinee self-regulation and test-taking motivation predict consequential and nonconsequential test performance? Contemporary Educational Psychology, 29, 6-26.

Taks, M. (2003). Zelfsturing in leerpraktijken: Een curriculumonderzoek naar nieuwe rollen van studenten en docenten in de lerarenopleiding [Selfregulation in learning practices: A curriculum research concerning new roles of students and teachers in teacher education]. (Doctoral dissertation, Twente University, the Netherlands). Retrieved from http://publishing.eur.nl/ir/repub/asset/9264/Sofie\%20Loyens\%20Proefschrift.pdf

Valle, A., Cabanach, R.G., Núñez, J.C., González-Pienda, J., Rodríguez, S., \& Piñeiro, I. (2003). Cognitive, motivational, and volitional dimensions of learning. Research in Higher Education, 44, 557-580.

VanderStoep, S.W., Pintrich, P.R., \& Fagerlin, A. (1996). Disciplinary differences in selfregulated learning in college students. Contemporary Educational Psychology, 21, 345362.

Van Eekelen, J.M., Boshuizen, H.P.A, \& Vermunt, J.D. (2005). Self-regulation in higher education teacher learning. Higher Education, 50, 447-471.

Petegem, P. Van, Donche, V., \& Vanhoof, J. (2005). Relating pre-service teachers' approaches to learning and preferences for constructivist learning environments. Learning Environments Research, 8, 309-332.

Van Hout-Wolters, B., Simons, R-J., \& Volet, S. (2000). Active learning: Self-directive learning and independent work. In New learning, 21-36. Dordrecht: Kluwer Academic Publishers. 
Vermunt, J.D., \& Verloop, N. (1999). Congruence and friction between learning and teaching. Learning and Instruction, 9, 257-280.

Vermunt, J.D., \& Vermetten, Y.J. (2004). Patterns in Student Learning: Relationships between learning strategies, conceptions of learning, and learning orientations. Educational Psychology Review, 16, 359-384.

Vermunt. J.D., \& Verschaffel, L. (2000). Process-oriented teaching. In P.R-J. Simons, J. van der Linden, \& T, Duffy [eds.], New learning (pp. 209-225). Dordrecht: Kluwer Academic Publishers.

Wigfield, A., Hoa, L.W., \& Klauda, S.L. (2007). The role of achievement values in the regulation of achievement behaviours. In D. H. Schunk, \& B.J. Zimmerman [eds.], Motivation and self-regulated learning (pp. 169-195). New York: Lawrence Erlbaum Associates.

Windschill, M. (2002). Framing constructivism in practice as the negotiations of dilemmas: An analysis of the conceptual pedagogical, cultural, and political challenges facing teachers. Review of Educational Research, 72: 131-175.

Wood, D., Bruner, J. S., \& Ross, G. (1976). The role of tutoring in problem solving. Journal of Child Psychology and Psychiatry, 17, 89-100.

Zimmerman, B.J. (1999). Commentary: Toward a cyclically interactive view of self-regulated learning. International Journal of Educational Research, 31, 545-551.

Zimmerman, B.J. (2000). Attaining self-regulation: A social cognitive perspective. In Handbook of self-regulation, 13-39. San Diego, CA: Academic Press.

Zimmerman, B.J. (2001). Theories of self-regulated learning and academic achievement: An overview and analysis. In B. J. Zimmerman, \& D. H. Schunk [eds.], Self-regulated 
learning and academic achievement: Theoretical perspectives (pp. 1-37). Mahwah, NJ: Lawrence Erlbaum.

Zimmerman, B.J. (2002). Becoming a self-regulated learner: An overview. Theory into Practice, 41, 64-70.

Zimmerman, B.J. (2007). Goal setting: A key proactive source of academic self-regulation. In D. H. Schunk, \& B.J. Zimmerman [eds.], Motivation and self-regulated learning (pp. 267295). New York: Lawrence Erlbaum Associates.

Zimmerman, B.J., \& Kitsantas, A. (2002). Acquiring writing revision and self-regulatory skill through observation and emulation. Journal of Educational Psychology, 94, 660-668 
Appendix A. Studies included in the analysis

\begin{tabular}{|c|c|c|c|c|c|c|}
\hline $\begin{array}{l}\text { Author } \\
\text { (Year) }\end{array}$ & $\begin{array}{l}\text { Type of } \\
\text { document }\end{array}$ & Location & $\begin{array}{l}\text { Empirical/ } \\
\text { Conceptual }\end{array}$ & $\begin{array}{l}\text { General/ } \\
\text { Secondary/ } \\
\text { Higher/Teach. Ed. }\end{array}$ & Main findings & Main themes \\
\hline Boekaerts (1999) & Journal article & NL & $\mathrm{C}$ & $\mathrm{HE}$ & $\begin{array}{l}\text { Internal, external, shared regulation } \\
\text { Development of metacognitive skills } \\
\text { Self-chosen goals }\end{array}$ & $\begin{array}{l}\text { Scaffolding } \\
\text { Modelling } \\
\text { Learning task }\end{array}$ \\
\hline Bolhuis \& Voeten (2001) & Journal article & NL & $\mathrm{E}$ & $\mathrm{SE}$ & Learning processes as social phenomena & Collaboration \\
\hline Bronnenman-Helmers (2007) & Report & NL & $\mathrm{C}$ & SE & Educational reform in the Netherlands & Importance \\
\hline Butler (2002) & Journal article & US & $\mathrm{C}$ & $\mathrm{SE} / \mathrm{HE}$ & $\begin{array}{l}\text { Instructional SRL model } \\
\text { Productive, unproductive attribution }\end{array}$ & $\begin{array}{l}\text { Content/metacognition } \\
\text { Learning task }\end{array}$ \\
\hline Butler \& Cartier (2004) & Journal article & US & $\mathrm{C}$ & $\mathrm{SE} / \mathrm{HE}$ & Effective task interpretation & Learning task \\
\hline Butler \& Winne (1995) & Journal article & US & $\mathrm{C}$ & $\mathrm{SE} / \mathrm{HE}$ & SRL Model including feedback & Learning task \\
\hline Dembo \& Eaton (2000) & Journal article & US & $\mathrm{C}$ & SE & $\begin{array}{l}\text { Academic achievement } \\
\text { Time management/ } \\
\text { Learning and performance goals }\end{array}$ & $\begin{array}{l}\text { Importance } \\
\text { Learning task }\end{array}$ \\
\hline Eccles \& Wigfield (2002) & Journal article & US & $\mathrm{E}$ & G & $\begin{array}{l}\text { Specific, proximal, challenging goals/ } \\
\text { Task-involved and performance goals }\end{array}$ & Learning task \\
\hline Eilam \& Aharon (2003) & Journal article & ISR & $\mathrm{C}$ & SE & $\begin{array}{l}\text { Academic achievement } \\
\text { Prior knowledge }\end{array}$ & $\begin{array}{l}\text { Importance } \\
\text { Learning task }\end{array}$ \\
\hline Eshel \& Kohavi (2003) & Journal article & ISR & $\mathrm{E}$ & SE & Classroom control, achievement & Importance \\
\hline
\end{tabular}




\begin{tabular}{|c|c|c|c|c|c|c|}
\hline & & & & & Student and teacher control & Knowledge building \\
\hline Hmelo-Silver, Duncan, \& Chinn (2006) & Journal article & US & $\mathrm{C}$ & G & $\begin{array}{l}\text { Academic achievement } \\
\text { Innovative approaches }\end{array}$ & $\begin{array}{l}\text { Importance } \\
\text { Scaffolding }\end{array}$ \\
\hline Hattie \&Timperly (2007) & Journal article & $\mathrm{NZ}$ & $\mathrm{C}$ & G & Feedback model & Learning task \\
\hline Kirschner, Sweller, \& Clark (2006) & Journal article & NL & $\mathrm{C}$ & G & Student guidance & Knowledge building \\
\hline Könings, Brand-Gruwel, \& van Merriënboer (2007) & Journal article & NL & $\mathrm{E}$ & SE & Teachers' professional development & Conditions \\
\hline Korthagen, Klaassen, \& Russell (2000) & Book chapter & NL & $\mathrm{C}$ & $\mathrm{TE}$ & Changing role of teachers & Importance \\
\hline Kramarski \& Michalsky (2009) & Journal article & ISR & $\mathrm{E}$ & $\mathrm{TE}$ & Instruction by teachers & Modelling \\
\hline Kremer-Hayon \& Tillema (1999) & Journal article & ISR & $\mathrm{E}$ & $\mathrm{TE}$ & Demands on organization and curricula & Importance \\
\hline Loyens (2007) & Dissertation & NL & $\mathrm{E}$ & $\mathrm{HE}$ & Students' conceptions & Importance \\
\hline Lunenberg \& Korthagen (2003) & Journal article & NL & $\mathrm{E}$ & $\mathrm{TE}$ & Teachers' professional development & Conditions \\
\hline Lunenberg \& Korthagen (2005) & Journal article & NL & $\mathrm{E}$ & $\mathrm{TE}$ & Teachers' professional development & Conditions \\
\hline Lunenberg, Korthagen, \& Swennen (2007) & Journal article & NL & $\mathrm{E}$ & TE & Teachers' professional development & Modelling \\
\hline Nicol \& Macfarlane-Dick (2006) & Journal article & UK & $\mathrm{C}$ & HE & Feedback principles & Learning task \\
\hline Nietfeld, Ciao, \& Osborne (2006 & Journal article & US & $\mathrm{E}$ & $\mathrm{HE}$ & Metacognition, academic achievement & Learning task \\
\hline Norton \& Hathaway (2010) & Book chapter & US & $\mathrm{E}$ & $\mathrm{TE}$ & Teachers' guidance & Collaboration \\
\hline Nota, Soresi, \& Zimmerman (2004) & Journal article & US & $\mathrm{E}$ & $\mathrm{HE}$ & Academic achievement & Importance \\
\hline Pintrich (2000) & Book chapter & US & $\mathrm{C}$ & $\mathrm{HE}$ & SRL Framework & Importance \\
\hline Pintrich (2004) & Journal article & US & $\mathrm{C}$ & $\mathrm{HE}$ & SRL Framework & Importance \\
\hline Putnam \& Borko (2004) & Journal article & US & $\mathrm{C}$ & $\mathrm{TE}$ & Teachers' professional development & Conditions \\
\hline Schunk (1999) & Journal article & US & $\mathrm{C}$ & G & Four levels & Modelling \\
\hline
\end{tabular}


Design Principles 30

\begin{tabular}{|c|c|c|c|c|c|c|}
\hline Schunk (2007) & Book chapter & US & $\mathrm{C}$ & $\mathrm{G}$ & Attributions, motivation, achievement & Learning task \\
\hline Schunk \& Ertmer (2000) & Book chapter & US & $\mathrm{C}$ & HE & Specific, proximal, challenging goals & Learning task \\
\hline Schunk \& Zimmerman (2007) & Journal article & US & $\mathrm{E}$ & G & Four levels & Modelling \\
\hline Simons, Van der Linden, \& Duffy (2000) & Book chapter & NL & $\mathrm{C}$ & $\mathrm{HE}$ & $\begin{array}{l}\text { Guided, action, experimental learning } \\
\text { Importance }\end{array}$ & $\begin{array}{l}\text { Scaffolding } \\
\text { Modelling }\end{array}$ \\
\hline Stijnen (2003) & Book & NL & $\mathrm{C}$ & G & Criticism SRL implementation & Importance \\
\hline Sundre \& Kitsantas (2004) & Journal article & US & $\mathrm{E}$ & $\mathrm{HE}$ & Academic achievement & Importance \\
\hline Taks (2003) & Dissertation & NL & $\mathrm{E}$ & $\mathrm{TE}$ & New roles of teachers and students & Conditions \\
\hline Valle et al. (2003) & Journal article & $\mathrm{SP}$ & $\mathrm{E}$ & $\mathrm{HE}$ & $\begin{array}{l}\text { Academic achievement } \\
\text { Learning goals, performance goals }\end{array}$ & $\begin{array}{l}\text { Importance } \\
\text { Learning task }\end{array}$ \\
\hline Van Eekelen, Boshuizen, \& Vermunt (2005) & Journal article & NL & $\mathrm{E}$ & $\mathrm{HE}$ & Teachers' SRL & Conditions \\
\hline VanderStoep, Pintrich, \& Fagerlin (1996) & Journal article & US & $\mathrm{E}$ & $\mathrm{HE}$ & Academic achievement & Importance \\
\hline Van Hout-Wolters, Simons, \& Volet (2000) & Book chapter & NL & $\mathrm{C}$ & G & Difficulties SRL implementation & Conditions \\
\hline Van Petegem, Donche, \& Vanhoof (2005) & Journal article & $\mathrm{BE}$ & $\mathrm{E}$ & $\mathrm{TE}$ & Students' preferences & Conditions \\
\hline Vermunt \& Verloop (1999) & Journal article & NL & $\mathrm{C}$ & HE & $\begin{array}{l}\text { Strong, shared, loose teacher control } \\
\text { Importance }\end{array}$ & $\begin{array}{l}\text { Scaffolding } \\
\text { Modelling }\end{array}$ \\
\hline Vermunt \& Vermetten (2004) & Journal article & NL & $\mathrm{C}$ & $\mathrm{HE}$ & $\begin{array}{l}\text { Process-oriented instruction } \\
\text { Gradual increase of student control }\end{array}$ & $\begin{array}{l}\text { Content/metacognition } \\
\text { Scaffolding }\end{array}$ \\
\hline Vermunt \& Verschaffel (2000) & Book chapter & NL & $\mathrm{C}$ & $\mathrm{HE}$ & $\begin{array}{l}\text { Process-oriented instruction } \\
\text { Gradual increase of student control } \\
\text { Epistemological perspective }\end{array}$ & $\begin{array}{l}\text { Content/metacognition } \\
\text { Scaffolding } \\
\text { Importance }\end{array}$ \\
\hline
\end{tabular}


Design Principles 31

\begin{tabular}{|c|c|c|c|c|c|c|}
\hline & & & & & Components & Conditions \\
\hline Wigfield, Hoa, \& Klauda (2007) & Book chapter & US & $\mathrm{C}$ & G & Facilitative role & Collaboration \\
\hline Windschill (2002) & Journal article & US & $\mathrm{C}$ & G & SRL Framework & Importance \\
\hline Wood, Bruner, \& Ross (1976) & Journal article & US & $\mathrm{E}$ & G & Gradual increase of student control & Scaffolding \\
\hline Zimmerman (1999) & Journal article & US & $\mathrm{C}$ & G & SRL Model & Importance \\
\hline Zimmerman (2000) & Book chapter & US & $\mathrm{C}$ & $\mathrm{G}$ & $\begin{array}{l}\text { SRL Model } \\
\text { Four levels }\end{array}$ & $\begin{array}{l}\text { Importance } \\
\text { Modelling }\end{array}$ \\
\hline Zimmerman (2001) & Book chapter & US & $\mathrm{C}$ & G & Theoretical SRL perspectives & Importance \\
\hline Zimmerman (2002) & Journal article & US & $\mathrm{C}$ & G & SRL Model & Importance \\
\hline Zimmerman (2007) & Book chapter & US & $\mathrm{C}$ & G & Advantageous properties of goals & Learning task \\
\hline Zimmerman \& Kitsantas (2002) & Journal article & US & $\mathrm{E}$ & $\mathrm{HE}$ & Academic achievement & Modelling \\
\hline
\end{tabular}

